\title{
The pathomorphologist's role in the era of personalised therapy regarding the case of colorectal tumours
}

\author{
Małgorzata Kołos ${ }^{1}$, Anna Nasierowska-Guttmejer ${ }^{1,2}$, Anna Wasążnik-Jędras ${ }^{1}$
}

Colorectal cancer is one of the most common epithelial tumours amongst humans. Effective treatment requires a multidisciplinary approach and in some cases target therapy. In order to introduce treatment, both the clinical stage and pathomorphological diagnosis have to be taken into account. An analysis of the microscopic appearance as well as immunohistochemical and molecular tests are the basis of proper diagnosis. Biomarkers for diagnosis of colorectal cancer can be divided into two groups. The first one constitutes diagnostic and prognostic markers which are commonly used by pathologists. They are useful in the recognition of morphological and clinical features of tumours. The second group of biomarkers is used additionally and has predictive value. In an era of personalised therapy, the pathomrothologist's role is to assess the prognostic and predictive biomarkers, in order to identify patients who will benefit from molecular targeted therapy. In the case of colorectal cancer mutations of genes: KRAS, NRAS and BRAF are clinically significant. A lack of the aforementioned mutations correlates with a better response to anti-EGRF therapy.

NOWOTWORY J Oncol 2016; 66, 5: 386-395

Key words: colorectal cancer, carcinogenesis pathways, prognostic biomarkers, predictive biomarkers, CIN, MSI, CIMP, BRAF mutations

\section{Introduction}

Colorectal cancer (13\% in males $[\mathrm{M}]$ and $10 \%$ in females [F]), breast cancer ( $23 \%$ in F), lung cancer (20\% in $\mathrm{M}$ and $9 \%$ in $\mathrm{F}$ ) and prostate cancer (15\% in M) in 2012 belonged to the most frequently diagnosed cancers and accounted for $48 \%$ of the total causes of diseases in men and $42 \%$ in women ( 65310 cases altogether) [1]. The above cancers are more and more frequently treated with personalised therapy, based on a detailed morphological report containing the evaluation of prognostic and predictive factors with immunochemistry and/or molecular reports. Modern oncological treatment requires, on the one hand, the collaboration of interdisciplinary teams consisting of diagnostic specialists, radiologists, pathologists, molecular biologists and clinicians (direct contact between the pathomorphologist and oncologist is of particular importance). On the other hand, however, the evaluation of the real costs of the pathological and morphological evaluation is necessary. Within the context of the wider debate on financing the treatment of patients at least one medical service such as chemotherapy, radiotherapy, surgical intervention or palliative care should be taken into account. According to the analyses of Kozierkiewicz at al. [2], the estimated expenses of the National Health Fund for the treatment of about 15000 cases of breast cancer per year, in 2004-2010, amounted to 2,893 billion PLN. This amount, however, does not take into consideration the diagnostics, which, in the case of oncological therapy (especially a molecularly targeted one) makes up a significant element on the costs list.

Colorectal cancer is an example of a cancer in which the patient prognosis and the treatment costs depend on the clinical stage at the moment of diagnosis. The choice of the

\footnotetext{
${ }^{1}$ Department of Pathomorphology

Central Clinical Hospital of the Ministry of the Interior and Administration, Warszawa, Poland

${ }^{2}$ The Faculty of Medicine and Health Sciences

The Jan Kochanowski University, Kielce, Poland
} 
treatment method is made on the basis of a pathological report with an evaluation of predictive factors. The correct result of microscopic examination depends significantly on the method of protecting the specimen collected during a surgery, its fixation method (the type of fixer and time of fixation) and the quality of the macroscopic evaluation [3]. Of special importance is the number of lymph nodes found (in the cancer of the colon) and the evaluation of the total mesorectal excision with the verification of the radial margin in the colorectal cancer. In the case of finding fewer than 12 lymph nodes in the colon surgery specimen, the patient undergoes adjuvant therapy, similar to that undertaken with palliative patients. The above parameters are the basis for the evaluation of the quality of the work of the surgeon and pathomorphologist [4]. The microscopic characteristics which are obligatorily evaluated are: histologic type and the tumour grade, the tumour stage in pTNM AJCC/UICC score, the features of the vessels and nerves involvement, surgical margins (distal, proximal and radial in segments of the large intestine without the serous membrane) and the degree of the tumour regression after the neoadjuvant therapy. The above parameters are listed in the recommendations of the Polish Society of Pathologists [4, 5].

In an era of targeted therapy, a modern pathology department requires special organisation. The requirements posed by oncologists for pathologists and molecular biologists have increased. The moments of key significance for the quality of the correct results of the immunohistochemistry $(\mathrm{IHC})$ and molecular tests are the pre-analytical stage (securing, preservation and technical processing of the tissue material), identification of the neoplastic tissue by the pathomorphologist for molecular tests and the validation and standardisation of the IHC and molecular methods. The work pattern in a modern pathology department according to the recommendations of the European and British pathological societies is illustrated in Figure 1 [6]. A pathomorphologist collaborating with an oncologist should have at their disposal a laboratory with automatic equipment which allow for obtaining repetitive results in the evaluation of biomarkers.

\section{Biomarkers in the diagnostics of colorectal cancer}

The biomarkers which are useful in the diagnostics of cancers can be divided into two groups. The first one comprises mainly immunohistochemistry biomarkers used by pathologists for routine diagnostics. In some selected cases, molecular methods are applied. They both have diagnostic and prognostic significance and are useful for the interpretation of morphological and clinical characteristics of neoplasms as they define the direction of cellular differentiation. Once applied in routine diagnostics processes, they allow for the determination of the histological type of primary tumour or establish the histological genesis of the metastasis. It must be stressed that they are subject to both external and internal control measures.

The latter group comprises the biomarkers with the predictive value, the usefulness of which has been evidencebased. They are recommended by clinicians and are used for the selection of treatment methods and monitoring the course of the disease. They can be divided into biomarkers whose expression is determined with immunohistochemistry methods and and/or the markers whose disorders in germinal or somatic cells are detected with molecular methods. They should undergo external quality control (EQC), which should be carried out among others by European organisations such as the European Society of Pathology (ESP) $[6,7]$.

\section{Diagnostic and prognostic biomarkers - group I}

The biomarkers within the first group are useful for a pathomorphologist to confirm the diagnosis of the histological type of the tumour. Sometimes the microscopic variant of a cancer or sarcoma has a prognostic value which has clinical significance for the course of the disease. The practical significance of biomarkers was applied for the diagnostics of colorectal cancers and its microscopic subtypes, neuroendocrine tumours, lymphomas and stromal tumours (GIST), and the most frequent mesenchymal cancers of the gastrointestinal tract.

The biomarkers of the first groups (both diagnostic and prognostic) are divided into two groups: those useful for differential diagnostics (IA) and for the identification of carcinogenesis pathways (IB).

\section{The biomarkers useful for differential diagnostics of colorectal cancers (IA)}

The immunohistochemistry-based differential diagnostics of colorectal cancers requires the application of antibodies' panel for immunohistochemistry tests. The guidelines for this type of diagnosis are discussed below.

\section{Adenocarcinoma}

The most frequent histological type of colorectal cancer is the adenocarcinoma. The biomarkers which confirm its epithelial differentiation comprise keratins which are characterised by a positive reaction to staining in the cytoplasm of the cancer cells for CK20 and predominantly negative cytoplasmic expression for CK7. The immunohistochemical profile of the types: CK7-/CK20+ is present in 95\% of colorectal cancers (and also in the majority of Merkel cell cancers and in almost one third of gastric adenocarcinomas) [8]. The marker which is useful in the case of the identification of a metastasis of a colorectal cancer to another organ or in the case of poorly differentiated primary colorectal cancer is the transcription factor CDX-2; the marker of proliferation and differentiation from the intestinal epithelium. It represents a positive nuclear reaction to staining in the cells of the normal 


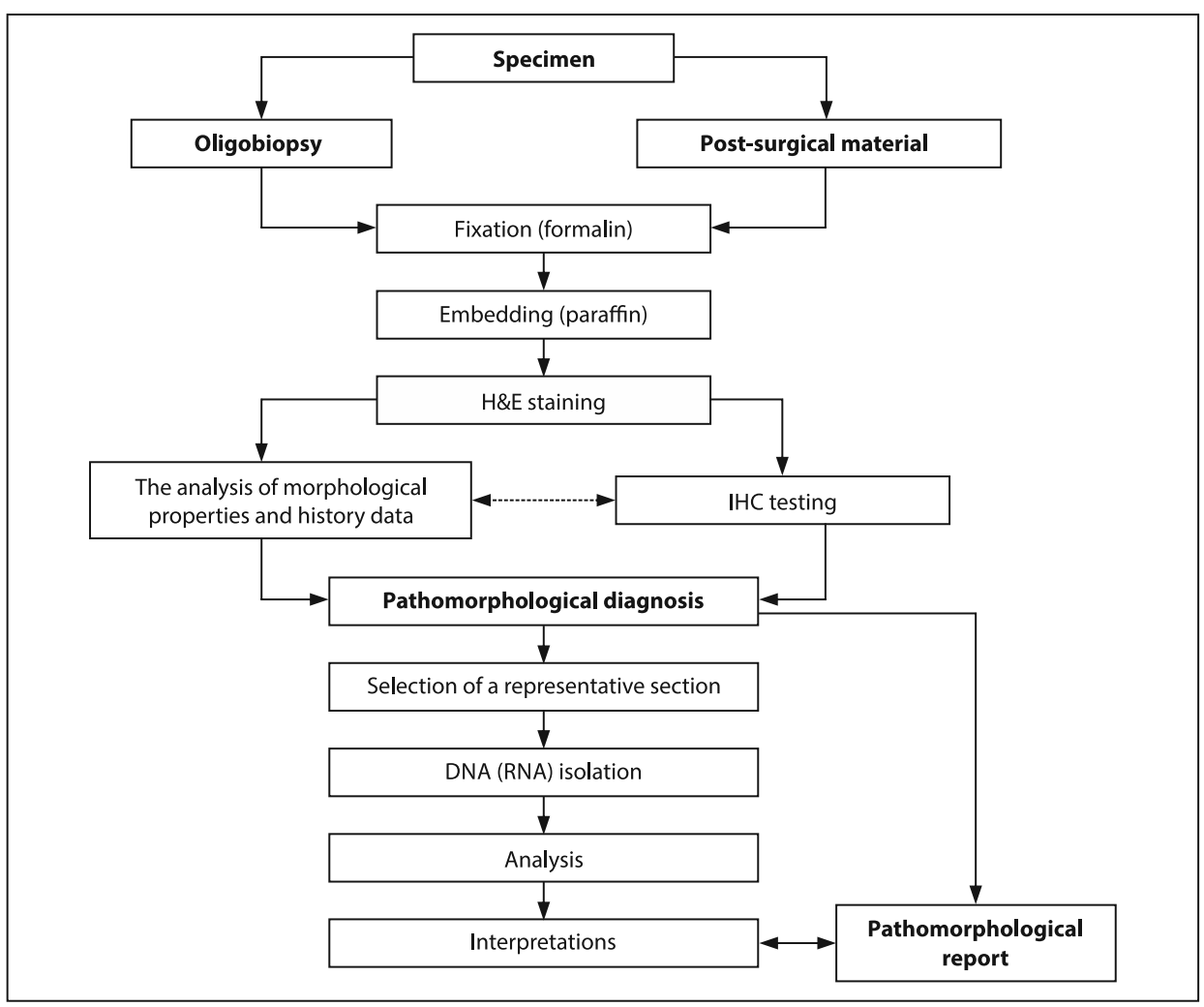

Figure 1. Work algorithm in a modern pathomorphology department (as modified by the authors on the basis of publication I. Cree [6])

mucosa of the large intestine and nuclear or nuclear and cytoplasmic reaction in the cells of the large intestine [9]. Moreover, ectopic CDX2 expression is found in $85 \%$ of acute myeloid leukaemias [10] and in the cases of Barrett's oesophagus in which the bile acids induce intestinal differentiation (metaplasia) of the cells of the gastric glandular epithelium [11, 12].

Recently there have been studies carried out concerning the usefulness of the AMACR antibody in the oncological supervision of patients with ulcerative colitis (UC). This antibody, used routinely in patients with prostate cancer does not manifest expression in normal large intestine mucosa, whilst it is present in the low degree dysplasia foci (96\%), high degree dysplasia foci (80\%) and in neoplastic infiltration (71\%) [13].

Apart from the above colorectal adenocarcinoma, in the discussed location, there are also other types of cancers. This group comprises the cancers with microsatellite instability (MSI) connected with hereditary nonpolyposis colorectal cancer (HNPCC - Lynch syndrome) or sporadic cancer. The antibodies panel which can confirm the cancers with MSI and differentiate them from the classical adenocarcinoma (CIN) comprises: the MLH1, MSH2, MSH6, PMS2 and TP53 antibody [14]. The differentiation of the classical adenocarcinoma, connected with poorer prognosis, from cancers with MSI, in particular of mucinous or medullary type, whose prognosis is better, has a great clinical significance.

\section{Neuroendocrine tumours}

Gastrointestinal neuroendocrine tumours require the confirmation of the diagnosis with the following immunohistochemistry tests: obligatorily Synaptophysin and Chromogranin A and, conditionally, CD56 or any other specific endocrine markers. In any case, it is necessary to evaluate the proliferative activity of $\mathrm{KI}-67$ (MIB1); a value below $20 \%$ confirms the diagnosis of neuroendocrine cancer (NEC). The above biomarkers have a diagnostic and prognostic value and proliferative index - has also predictive value.

\section{Stromal tumour of the alimentary tract (GIST)}

GIST is another example of the alimentary tract tumour which requires special pathological diagnostics with the use of biomarkers. In comparison with other segments of the digestive tract, it occurs quite rarely in the large intestine ( $5 \%$ of cases in the anus and 1\% of cases in the colon). It must be stressed that GIST in distal location has a significantly poorer prognosis than in a proximal one [15]. The progression risk of large intestine GIST in the cases with more than 5 division figures into 50 large visual fields and a diameter ranging from 5 to $10 \mathrm{~cm}$ is $85 \%$ in comparison with $55 \%$ in the case of stomach GIST [16]. In a microscopic evaluation, GIST manifests a heterogenous microscopic appearance with an epithelioid, spindle or polymorphic cell. That is why the IHC evaluation of the biomarkers expression, and, in some cases also the molecular tests of the KIT and PDGFRA 
Table I. The panel presenting immunohistochemical differential diagnostics confirming the histological genesis of a tumour

\begin{tabular}{ll}
\hline Cancer type & IHC panel for differential diagnosis \\
\hline Large colon adenocarcinoma & CK20, CDX-2, CK7 \\
Large colon neuroendocrine tumours & Obligatory: Synaptophysin, Chromogranin A, Ki-67 \\
& Conditional: CD56 \\
Obligatory: CD117 \\
CIST of the large colon & Conditional: DOG1, CD34, H-Caldesmon, SMA, S100, Calponina, HMB45, Melan A, S100, \\
& PLAP, CD30, D2-40, $\beta$-catenin \\
Lymphomas & LCA, CD3, CD20, BCL2 \\
Muscle type neoplasms & SMA, Desmina, H-Caldesmon \\
Nerve type neoplasms & S100, GFAP \\
Myofibroblastic neoplasms & ALK1, Desmina, SMA \\
Vascular type neoplasms & CD31, D240 \\
\hline
\end{tabular}

genes mutation confirm GIST diagnosis and differentiate it with other large colon neoplasms. The tests which confirm the diagnosis of this lesions are: immunohistochemical expression of CD117 (KIT) [17], membranous type of reaction (discohesive, hypercellular and sarcomatous types of GIST), perinuclear or pancytoplasmatic stain (spindle cell type of GIST) as well as Anoctamine 1 (DOG1) found in $100 \%$ of cases [15]. It must also be observed that the lack of CD117 expression may be indicative of PDGFRA mutation. About $80 \%$ of GIST CD117 negative tumours manifest a PDGFRA gene mutation, whilst the remaining cases (10-15\%) are wild type tumours (WT). They manifest neither KIT not PDGFRA mutations. Less specific GIST biomarkers are CD34 (60-70\%), H-Caldesmon (85\%), SMA (30-40\%), S100 (5\%) and Calponina (9). In some selected cases, it is recommended to carry out a differential diagnosis with melanoma (HMB45, Melan A or S100 antibodies), seminoma (PLAP, CD30), dysgerminoma (D2-40) or an aggressive fibromatosis type lesion (nuclear expression of $\beta$-catenin) [16].

\section{Lymphomas and mesenchymal cell tumours} with a definite differentiation direction

Lymphomas and mesenchymal cell tumours with a definite direction of differentiation whose prevalence in the large colon is quite rare, require the conformation with $\mathrm{ICH}$ biomarkers, and sometimes with molecular tests. Their diagnostics should be performed in oncological centres. Some specific tumour types with a useful panel of immunohistochemistry tests are presented above (Tab. I).

\section{The biomarkers of colorectal cancer}

carcinogenesis pathway (IB)

The second group of diagnostic and prognostic biomarkers comprises the biomarkers of the neoplastic transformation pathway of the colon epithelium. Adenocarcinomas develop of the basis of three carcinogenic pathways. There are cancers with chromosomal instability (CIN), satellite instability (MIN) and cancers with CpG islands instabi- lity $[18,19]$. The above division is presented on Figure 2 . Such lesions may occur as a result of genetic disorders (mutations and changes of the cellular DNA) or epigenetic disorders (gene modifications with DNA methylation) [20]. The panel immunohistochemistry markers:TP53, MLH1, MSH2, MSH6, PMS2 allow for a preliminary determination of the pathway of neoplastic transformation, differentiating cancers with MSS from cancers with MSI-H and MSI-L $[18,19]$. The evaluation of germinal mutations of $A P C$ genes and $M M R$ genes has a prognostic value.

\section{APC gene mutations}

In the cases of a classical CIN carcinogenesis pathway, the $A P C$ gene mutation and activation of the Wnt pathway occurs and is responsible for about $90 \%$ of cases of cancers of the large colon [21]. A small number of large colon cancers (less than $1 \%$ ) is hereditary and occurs as a result of the germinal mutation of the APC gene (familial adenomatous polyposis - FAP) or MUTYH gene mutation (MUTYH-related polyposis) $[22,23]$. The germinal mutation of the $A P C$ gene, in comparison with the somatic mutation of this gene, has a prognostic value, as it identifies the patients burdened with a risk of the development of colorectal cancer at a young age. The mean age of the person in whom this cancer develops is 40 years. The risk of development at the age of 21 varies between $1 \%$ and $6 \%$, whilst at the age of 50 years, it is more than $95 \%$ [24].

In sporadic cancers, the somatic mutations of the APC gene occur. Also the mutations of the function loss concerning the TP53 suppressor gene (known as "the guardian of the genome"), are found in such cases. Overexpression of the TP53 protein can be diagnosed with the immunohistochemistry method. The nuclear accumulation occurs at an early stage of the neoplastic transformation to intraepithelial neoplasia. It must be stressed that the confirmation of the TP53 gene mutation is done by molecular tests. A microscopic image of the tubular adenoma together with the immunohistochemistry evaluation of the TP53 protein is presented in Figures $3 a$ and $3 b$. 


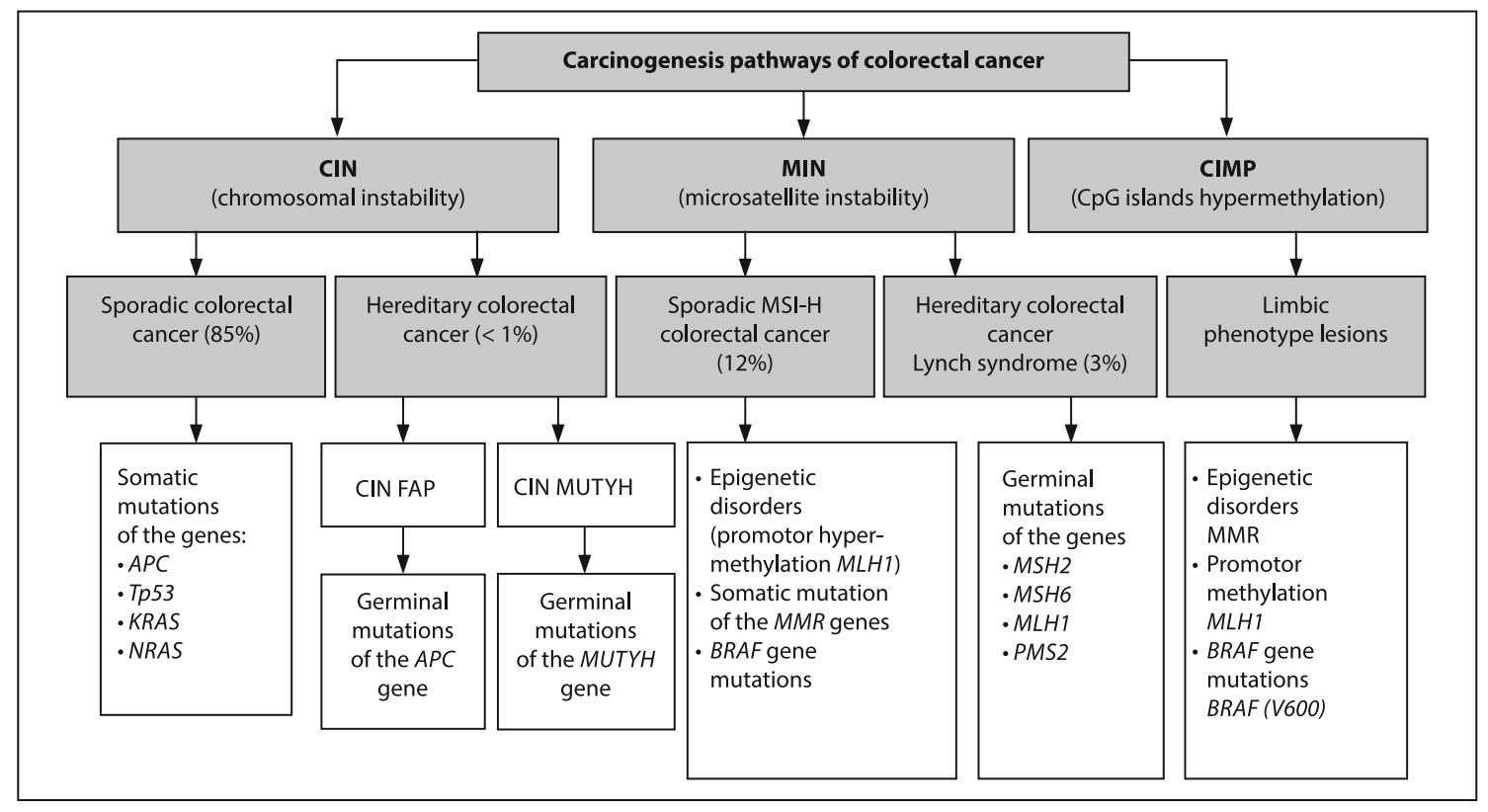

Figure 2. Carcinogenesis pathways of colorectal cancer

\section{MMR genes mutations}

The pathway connected with microsatellite instability (MIN) is responsible for the development of Lynch syndrome (polyposis-related hereditary large colon cancers, making up $3 \%$ of large colon cancers) and for sporadic cancers ( $12 \%$ of large colon cancers) $[25,26]$. In these cases, there is a mutation of mutator genes coding the proteins taking part in the mismatched nitrogen bases (MMR - mismatch repairgenes).

The evaluation of the loss of immunohistochemistry expression of the MLH1, MSH2, MSH6, PMS2 proteins (lack of colour nuclear reaction) allows to diagnose the mutator subtype of cancer. The diagnostic and prognostic value of IHC and the molecular test is justified in these cases. The germinal mutations of MMR genes can conform Lynch syndrome (autosomally dominating with mutations of at least one of the MMR genes) or Muir-Torre syndrome (MTS) (autosomally dominating with mutations of the $\mathrm{MSH} 2$ gene, more rarely of $M L H 1$ ), which, together with a family history may identify the families burdened with a risk of multiple synchronous or metachronous cancers with MSI.

In sporadic cancers, there are somatic mutations of $M M R$ genes or epigenetic disorders, such as hypermethylation. It is significant that the first stage in the diagnostics of large colon cancers with MSI consists in macro and microscopic features, such as right-side location, histological type and heterogenicity of the architecture, the presence of mucus and signet ring cells, type of inflammatory infiltrates, the presence of necrosis and the type of tumour growth margins. The next stage is the performance of $\mathrm{IHC}$ and molecular tests.

\section{CpG Islands hypermethylation (CIMP)}

The third carcinogenesis pathway consists in silencing suppressor genes responsible for the regulation of the transcriptions in the mechanism of the CpG islands hypermethylation. The precursor changes of large colon cancers occurring through the CIMP are serrated changes, accompanied by BRAF gene mutations (V600), the methylations of the promotors of various genes and the methylations of the $M L H 1$ promotor. Large colon cancers with CIMP are more frequent in women, in right-side location and have MSI-H microscopic features [14]. The immunohistochemistry evaluation of MLH1 allows the detection of the loss of protein expression in a tumour. The prognostic significance of this carcinogenic pathway is still under discussion.

\section{Predictive biomarkers - II group}

The basis for the implementation of targeted therapy in cancer patients is the determination of the factor connected with the target of the drug effect and identification of patients who would benefit from the treatment. In practise, the qualification of the patients for treatment requires the obligatory evaluation of predictive factors studied by a pathologist as well as a molecular biologist. The immunohistochemistry evaluation of the expression of the proteins produced by the selected genes or molecular changes of these genes allow one to predict an individual response to treatment.

The patients with advanced stage of disease, with distant metastases (stage IV) are recommended to receive targeted therapy with EGFR inhibitors: cetuximab and panitumumab, monoclonal antibodies directed at extracellular 


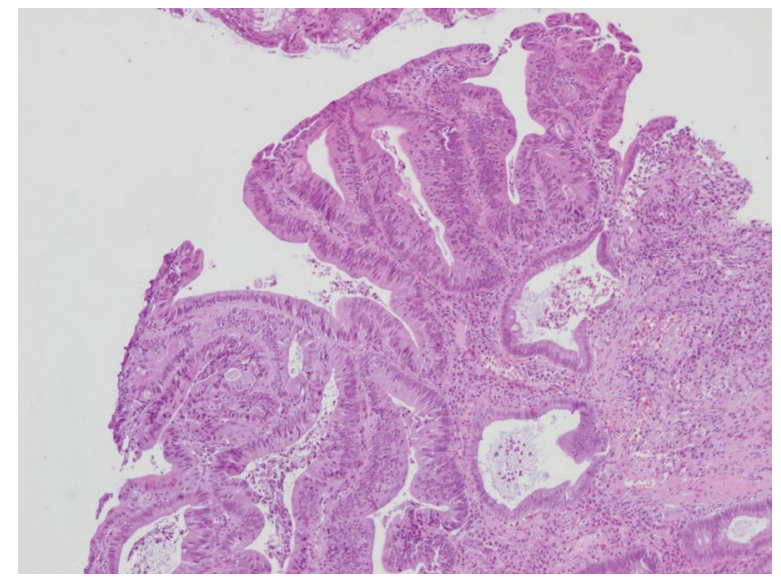

Figure 3a. Colorectal tubular adenoma with high degree endothelial dysplasia/neoplasia, H\&E staining, magnitude: 100×

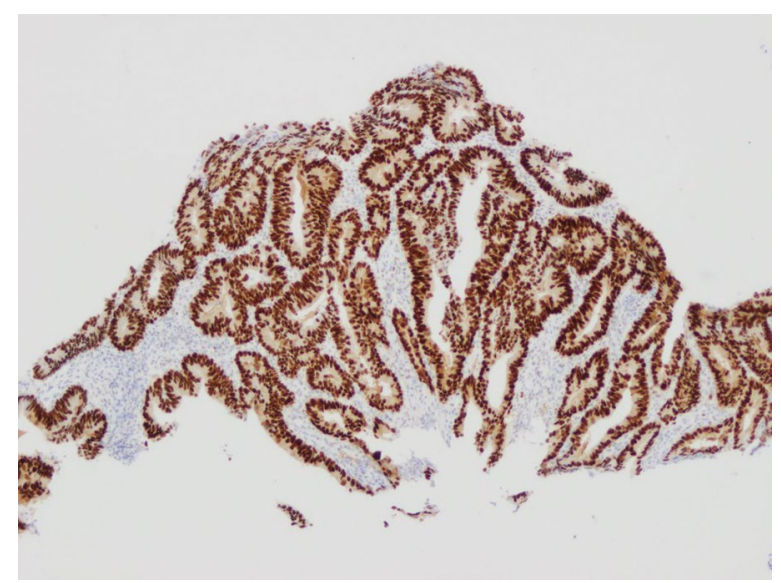

Figure 3b. Colorectal tubular adenoma with high degree endothelial dysplasia/neoplasia, IHC — protein accumulation TP53, magnitude: 40×

domain and small particles of tyrosine kinases inhibitors. EGFR, belonging to the family of tyrosine kinase inhibitors, is a defined target in the therapy of colon cancer. Its overexpression, found in numerous solid tumours, is also a cause of a poor prognosis in these patients. Before the implementation of an anti-EGFR therapy, it is necessary to evaluate the predictive factors connected with intracellular signalling pathways (IIA group biomarkers). The practical significance of the biomarkers connected with the carcinogenesis pathways of large colon cancers, such as WNT (IIB group), and epigenetic disorders with MSI (IIC group), is still at the clinical trial stage.

\section{Biomarkers of intracellular signalling pathways (IIA)}

Anti-EGFR therapy in the treatment of colorectal cancer is directed at somatic molecular disorders of the genes leading to the activation of the intracellular signalling pathways:
RAS - RAF - miogen-activated protein kinase (MAPK), phosphatidylinositol 3-kinase (PIK3K) - AKT and phospholipase $C$ (EGFR/RAS/RAF/MEK/MAPK, PTEN/PIK3K). In normal situation, this pathway is controlled by EGFR. In the case of EGFR overexpression and the activation of the signalling pathway the neoplastic cells are activated and thus the cancer cells proliferate, apoptosis is inhibited and their survival time is prolonged. This leads to an increased cancer invasion, increased angiogenesis, growth of distant metastases and cancer progression.

The activation of the intracellular signalling pathways is the outcome of dimerization and phosphorylation resulting from the connection of EGF (epidermal growth factor) or any other ligand with EGFR [27]. Another cause are the mutations of KRAS, NRAS, BRAF and PIK3K genes located in the lower part of the EGFR signalling pathway, not controlled by EGFR. PIK3K mutations may occur simultaneously with the mutations in KRAS or BRAF genes, whilst KRAS and BRAF mutations occur independently. Moreover, mutations in 12,13,61, 146 codons of the KRAS gene and mutations V600E of the BRAF gene initiate an independent route of pathway activation, a permanent activation of the MEK protein kinase, and, as a consequence, the failure of the anti-EGFR therapy. The proliferation pathway of the colorectal cancer is presented on Figure 4.

Immunohistochemical evaluation of the EGFR protein expression was not regarded as a predictive factor and no patient should be excluded from the treatment with anti-EGFR antibodies on the basis of immunohistochemical lack of EGFR protein expression [29, 30]. This results, among others, from the fact that the outcome of the reaction might be uncertain as it depends, to a large degree, from the method of preserving the tissue and the period of the storage of the material [31]. In accordance with the NCCN (National Comprehensive Cancer Network) guidelines, it is recommended to identify KRAS and NRAS mutations in all patients with advanced colorectal cancer (stage IV) [32]. In July 2013 the European Medicines Agency (EMEA) updated the qualification criteria for anti-EGFR therapy, recommending obligatory identification of KRAS and NRAS mutations in exons 2,3 and $4[33,34]$.

The analysis of the mutations in KRAS, NRAS, BRAF and $P I K 3 K$ genes has a predictive value. It identifies the patients who will not benefit from the anti-EGFR therapy. The mutation of the KRAS gene, present in $35 \%$ to $45 \%$ cases of colorectal cancer has the highest clinical value. It is a significant predictive factor of the resistance to the treatment with cetuximab and panitumumab. The mutations of the $B R A F$, PIK3CA genes and the loss of PTEN expression are also included into the predictive factors of colorectal cancer [35]. They predict the lack of response to the treatment with anti-EGFR antibodies. Their application in practice, however, requires some further clinical research. 


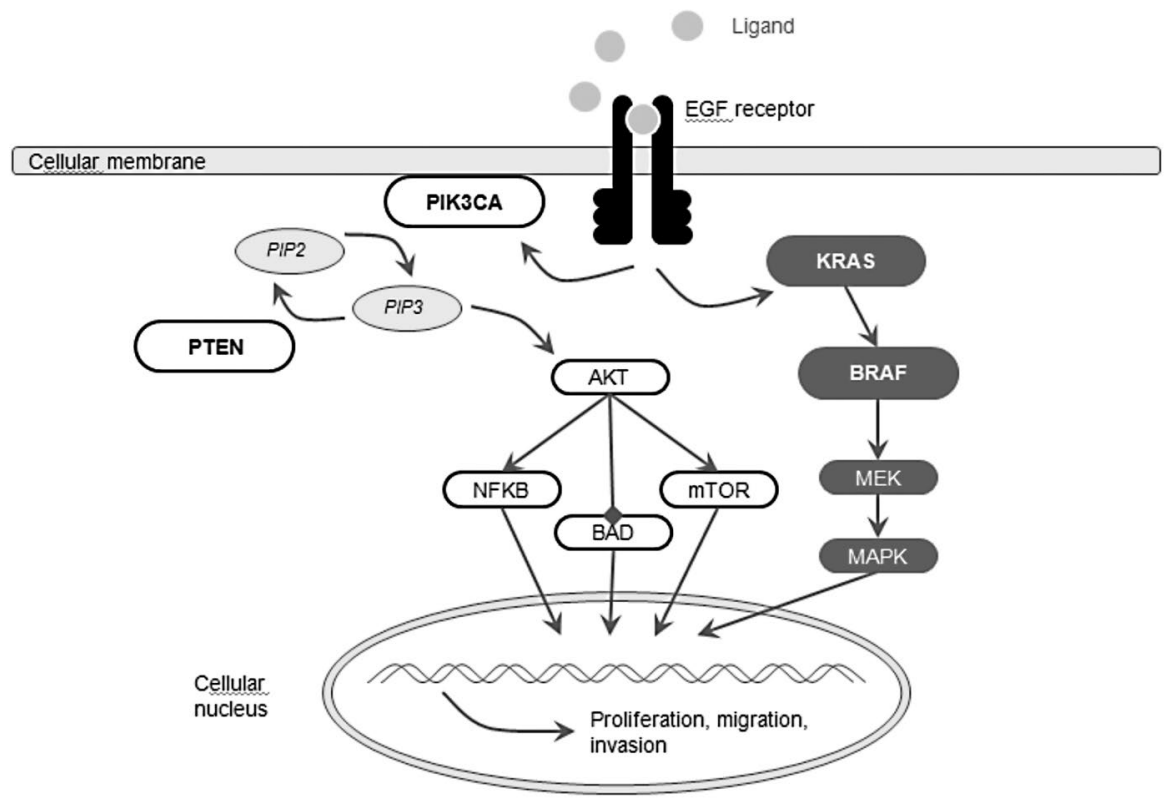

Figure 4. Colorectal cancer proliferation pathway (the authors own work on the basis of M. Berg's publication [28])

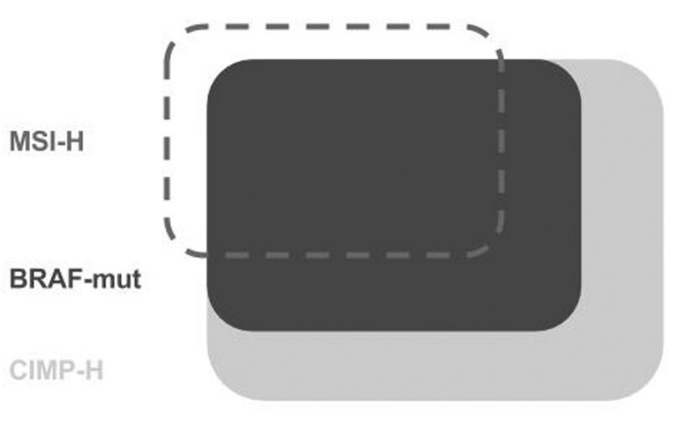

Figure 5. Relationship between CIMP, MSI and BRAF

\section{BRAF gene mutation (IIA)}

The BRAF gene mutation (IIA) occurs in less than $15 \%$ cases of the colorectal cancer and in $90 \%$ cases it concerns V600E codon. BRAF is serine/threonine kinase activating MAP/ERK kinases from the RAF family leading to the activation of MEK and, EGFR-independent proliferation of cancer cells (Fig. 4) [36]. The mutations of the BRAF gene correlate with the MSI molecular subtype and the phenotype of the mutated CpG islands. The correlation between MSI, CIMP and BRAF is illustrated on Figure 5.

Cancers with the BRAF gene mutation have different phenotypes from the wild types, without any mutations. In such cases, the patients are mostly women above 70 years of age with tumours located in the proximal part of the colon. Here mucinous and poorly differentiated cancers are dominating with metastases mostly to the lymph nodes and more rarely to the lungs $[36,37]$. The BRAF mutation indicates an adverse course of the disease [38], yet its prediction significance still remains an issue that requires some further research [34]. The $B R A F$ gene, a modulator of the MAPK pathway, may become a promising target of personalised therapy as a resistance biomarker. The research shows that it is responsible for about $12-15 \%$ of failures of the anti-EGFR therapy [36, 39]. According to the studies of Richman et al., identifying the $B R A F$ gene mutation may be a valuable predictive factor for a poor response to cetuximab, however, it is not a predictive factor for the therapy with the use of irinotecan or oxaliplatin [40].

\section{PIK3K gene mutations (IIA)}

PIK3K gene mutations occur in $20 \%$ or less than $20 \%$ of cases of colorectal cancer. They are connected with an adverse course of the disease and the lack of response to treatment with anti-EGFR antibodies. The predictive value of this gene is more useful in connection with the evaluation of the expression of PTEN, a negative regulator of apoptosis inhibition pathway and cell proliferation [34]. In accordance with the current state of knowledge, mutations in exons 9 and 20 PIK3K may be the cause of cetuximab and panitumumab resistance.

\section{Wnt pathway (IIB)}

The most frequently occurring somatic mutation in colorectal cancer is the mutation of the APC gene $(80 \%$ of cases), which activates the Wnt signalling pathway. The loss of function of the APC protein impairs $\beta$-catenin phosphorylation, and this substance, accumulated in the cell nucleus, potentiates the expression of the genes stimulating the proliferation processes [41]. Currently there are attempts made at inhibiting this pathway with the use of 


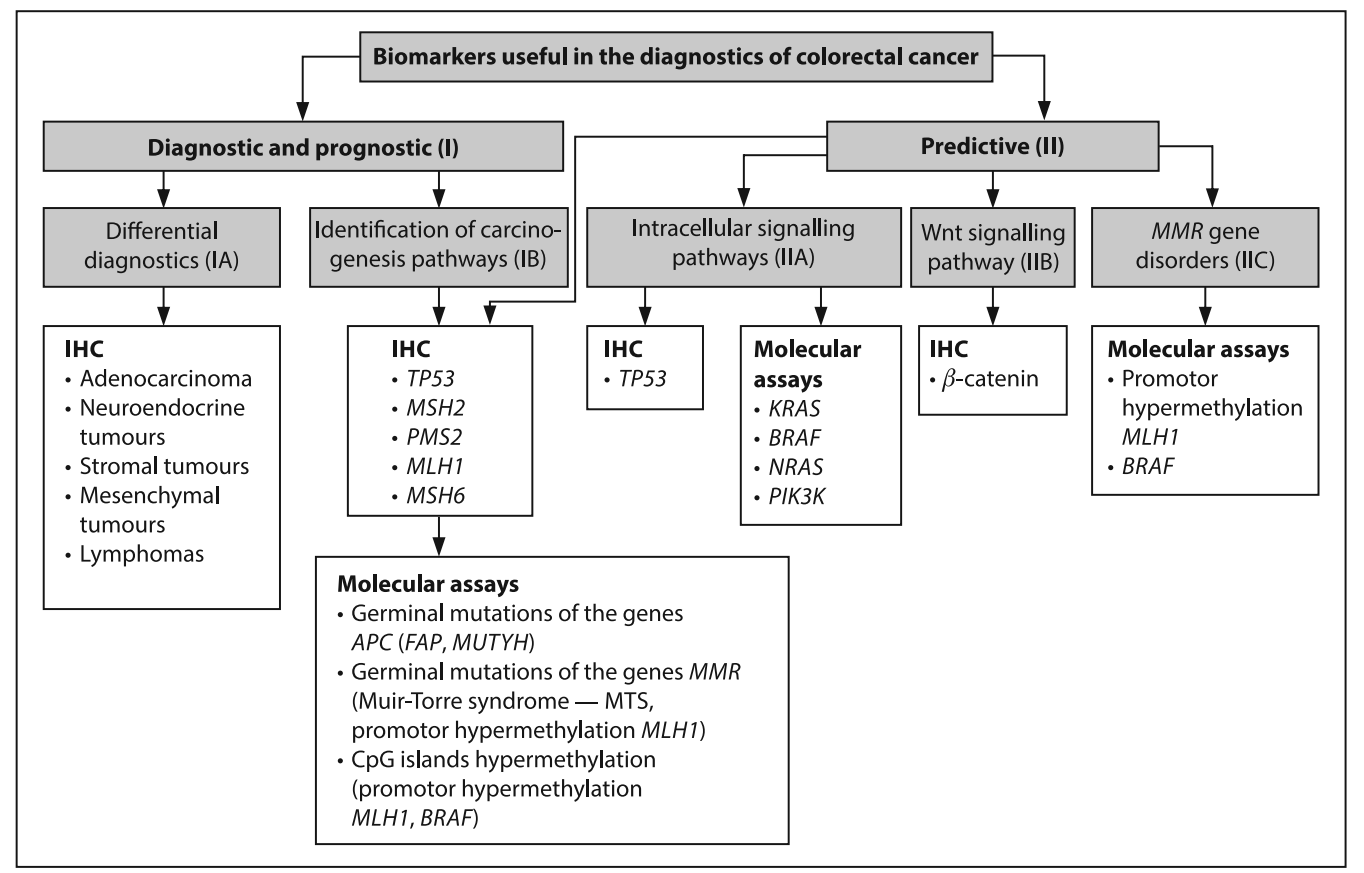

Figure 6. A list of biomarkers useful in the diagnostics of colorectal cancer

the available therapeutic agents, yet no efficient inhibitors have been found. As for the time being, the status of a predictive marker for the Wnt pathway may belong to immunohistochemistry evaluation of the nuclear $\beta$-catenin expression, which points to increased proliferation [42].

\section{MMR gene disorders (IIC)}

About $15 \%$ of cases of colorectal cancers display the disorders of the MMR mutator genes. The majority of them are cases of sporadic cancer, in which there are somatic mutations and epigenetic disorders, most frequently the hypermethylations of the $M L H 1$ gene promotor. Inactivation of the MSH2 and MSH6 genes occurs much less frequently [43]. In these cases the evaluation of the methylation of the $\mathrm{MLH} 1$ gene promotor has a predictive value. It allows the selection of a group of patients with a cancer of the MSI-H type with a similar microscopic image to Lynch syndrome, yet with a different phenotype. It must be stressed that $70 \%$ of cases of colorectal cancers with MLH1 hypermethylation display the BRAF gene mutation, which is a predictive factor in anti-EGFR therapy (cetuximab and panitumumab).

The IHC test of MLH1 hypermethylation and the analysis of BRAF V600E mutations are predictive factors in sporadic cancers with MSI-H. An immunohistochemistry test is a better and less expensive method than the molecular examination of the mutations of the MMR mutator genes. Apart from the above biomarkers which are useful in targeted therapies, the evaluations of topoisomerase inhibitors, PARP1 inhibitors and PI3K-AKT-mTOR pathway inhibitors are also useful.

Moreover, patients with sporadic colorectal cancers with MSI-H do not benefit from the classical adjuvant thera- py which is based on 5-Fluorouracil, yet the cancer cell lines may be more sensitive to treatment with irinotecan [44].

The summary of diagnostic, prognostic and predictive biomarkers as well as carcinogenesis paths with a useful set of immunohistochemicalis and molecular tests is presented below (Fig. 6).

\section{miRNA as a prognostic and predictive marker}

A prognostic and predictive marker as well as a potential target of the therapy is microRNA (miRNA). This is a class of small, endogenous, single-stranded RNA, which play a role as post-transcriptive regulators taking part in carcinogenesis, invasion and progression of colorectal cancer $[45,46]$. The work published in 2014 by Stiegelbauer et al. presents the characteristics of the miRNA studied so far together with their predictive value in the therapy of the patients with colorectal cancer.

\section{Morphological and molecular classifications}

During recent years there have been attempts to create morphological and molecular classifications which could divide patients into groups correlating with responses to treatment. None of the many publications concerning colorectal cancer, such as Jass's classification from 2007 [47], Furlan's from 2011 or Sadanandam's [48] or Roepman's from 2014, found application and general approval in clinical practice. It was shown, however, that the classifications based on cellular phenotype and the molecular disorders connected with carcinogenesis have a larger value than classifications based solely on the molecular phenotype (e.g. those based on micro-RNA analysis). 


\section{Summary}

Analysis of biomarkers in colorectal cancer requires, from a pathologist, the application of immunohistochemistry methods and molecular studies for the diagnostics. The first group of biomarkers has diagnostic and prognostic significance. It should be routinely available in pathology departments dealing with histopathological oncological diagnostics. The latter group comprises the biomarkers with predictive significance in respect to molecularly targeted therapy. They are analysed with both immunochemistry and molecular methods, which should be based on validated techniques, subject to quality control.

The clinical significance of the evaluation of predictive factors consists of the correct qualification of patients for the therapy oriented at the regulation of the disorders leading to carcinogenesis and whose aim is the selective destruction of cancer cells. On the basis of the analysis of biomarker expression, the patients who will not benefit from such treatment are identified. There are two strategies for selecting patients for the therapy which is molecularly oriented. The first one is connected with identification of the factor connected with the drug effect, whilst the other strategy consists of the identification of the patients who will benefit from the treatment. The determination of the predictive factors allows therefore to exclude the patients who will not benefit from personalised therapy. In the area of clinical trials, new predictive factors come up and they are able to predict the efficacy of a drug in a connection with its target.

The analysis of prognostic and diagnostic factors enlarges the standard scope of pathological diagnostics by taking histogenesis and molecular disorders which are the core of cancer development into account. In the era of targeted therapy, the pathological diagnostics concerns three directions, as recommended by ASCO/CAP 2015: 1. The evaluation of microsatellite instability as a prognostic and predictive factor in patients with MSI-H in Lynch syndrome and in sporadic cancer; 2 . The evaluation of predictive factors in cancers with MSI-H on the basis of IHC analysis of $\mathrm{MLH} 1$ hypermethylation and the analysis of the BRAFV600E mutation; 3. The molecular analysis of the status of the KRAS and NRAS genes as a predictive factor of the lack of response to the anti-EGFR therapy.

\section{Conflict of interest: none declared}

\author{
Małgorzata Kołos, MD \\ Department of Pathomorphology \\ Central Clinical Hospital of the Ministry of the Interior \\ and Administration \\ Wołoska 137, 02-507 Warszawa, Poland \\ e-mail:malgosia.kolos@gmail.com
}

Received: 30 Mar 2016

Accepted: 6 Jun 2016

\section{References}

1. Wojciechowska U, Didkowska J. Nowotwory złośliwe w Polsce w 2012 roku. Nowotwory J Oncol 2014; 63: 197-216.

2. Kozierkiewicz A, Śliwczyński A, Pakulski M et al. Wydatki na leczenie raka piersi w Polsce. Nowotwory J Oncol 2013; 63: 217-226.

3. Nasierowska-Guttmejer A. Najczęstsze błędy na linii onkolog - patomorfolog. Onkologia po Dyplomie 2014; 11: 26-31.

4. Nasierowska-Guttmejer A. Zasady postępowania z materiałem operacyjnym u chorych na raka jelita grubego - przygotowanie materiału tkankowego do badania histologicznego. PolJPathol2014;65 (4Suppl 1): S37-S39.

5. Nasierowska-Guttmejer A. Zasady postępowania z materiałem operacyjnym u chorych na raka jelita grubego - standardowe i wysokospecjalistyczne badania dodatkowe w raku jelita grubego. Pol J Pathol 2014; 65 (4 Suppl 1): S40-S50.

6. Cree I, Deans Z, Lightenberg J et al. Guidance for laboratories performing molecular pathology for cancer patients. J Clin Pathol 2014; 67: 923-931.

7. Van Krieken J, Jung A, Kirchner T et al. KRAS mutation testing for predicting response to anti- EGFR therapy for colorectal carcinoma: proposal for an European quality assurance program. Virchows Arch 2008; 453: 417-431.

8. Rosai J. Rosai and Ackerman's Surgical Pathology. 10th ed. Edinburgh: Mosby Elsewier, 2011: 54-55.

9. Olsen J, Espersen $M L$, Jess $P$ et al. The clinical perspectives of CDX2 expression in colorectal cancer: a qualitive systematic review. Surg Oncol 2014; 23: 167-176.

10. Scholl C, Bansal D, Dohner $\mathrm{K}$ et al. The homeobox gene CDX2 is aberrantly expressed in most of cases of acute myeloid leukemia and promotes leukemogenesis. J Clin Invest 2007; 117: 1037-1048.

11. Debruyne PR, Witek M, Gong L et al. Bile acids induce etopic epressionof intestinal guanylyl cyclase $C$ through nuclear factor-kappB and CDX2 in human esophageal cells. Gastroenterology 2006; 130: 1191-1206.

12. Liu $\mathrm{Q}$, Teh $\mathrm{M}$, Ito $\mathrm{K}$ et al. CDX2 expression in progressively decreased in human gastric intestinal metaplasia, dysplasia and cancer. Modern Pathology 2007; 20: 1286-1297.

13. Bressenot A, Cahn V, Danese $S$ et al. Microscopic features of colorectal neoplasia in inflammatory bowel disease. World J Gastroenterol 2014; 20: 3164-3172.

14. Kołos M, Wasążnik-Jędras A, Nasierowska-Guttmejer A.Can the histological type of colorectal cancer determine the carcinogenesis pathway? Pol J Pathol 2015; 66: 109-120.

15. Guzińska-Ustymowicz K, Nasierowska-Guttmejer A. Nowotwory podścieliskowe przewodu pokarmowego.PolJPathol2013;64(4Suppl 2); S47-S54.

16. Nasierowska-Guttmejer A.Nowotwory podścieliskowe przewodu pokarmowego (GIST). In: Mięsaki tkanek miękkich. Jeziorski A, Rutkowski P (eds.). Gdańsk: Via Medica 2015: 130-134.

17. Miettinen $M$, Lasota J. Gastrointestinal stromal tumors review on morphology, molecular pathology, prognosis, and differential diagnosis. Arch Pathol Lab Med 2006; 130: 1466-1478.

18. Bosman F, Yan P. Molecular pathology of colorectal cancer. Pol J Pathol 2014; 65: 257-266.

19. Setaffy $L$, Langner $C$. Microsatellite instability in colorectal cancer: clinicopathological significance. Pol J Pathol 2015; 66: 203-218.

20. Coppede F, Lopomo A, Spisni R et al. Genetic and epigenetic biomarkers for diagnosis, prognosis and treatment of colorectal cancer. World J Gastroenterol 2014; 20: 943-956.

21. Giles RH, van Es JH, Clevers H. Caught up in a Wnt storm: Wnt signaling in a cancer. Biochim Biophys Acta 2003; 1653: 1-24.

22. Bedeir A, Krasinskas AM. Molecular diagnostics of colorectal cancer. Arch Pathol Lab Med 2011; 135: 578-587.

23. Klusek J, Głuszek S. Wybrane mutacje związane z dużym ryzykiem wystąpienia nowotworów jelita grubego. Przegląd Gastroenterol 2012; 7: 1-6.

24. Deptała A (ed.). Rak jelita grubego. Poznań: Termedia Wydawnictwa Medyczne, 2012.

25. Lynch HT, Lanspa SJ, Boman BM et al. Hereditary nonpolyposis colorectal cancer - Lynch syndromes I and II. Gastroenterol Clin North Am 1988; 17: 679-712.

26. Cunningham JM, Christensen ER, Tester DJ et al. Hypermethylation of the hMLH1 promoter in colon cancer with microsatellite instability. Cancer Res 1988; 58: 3455-3460.

27. Olszewski WP, Olszewski WT. Rola patomorfologa w doborze terapii ukierunkoweanej na receptor czynnika wzrostu naskórka (EGFR) u chorych na nowotwory. Onkol Prak Klin 2010; 6: 228-235. 
28. Berg M, Soreide K. EGFR and downstream genetic alterations in KRAS/ /BRAF and PI3K/AKT pathways in colorectal cancer: implications for targeted therapy. Discov Med 2012; 14: 207-214.

29. Hecht JR, Mitchell E, Neubauer MA et al. Lack of correlation between epidermal growth factor receptor status and response to Panitumumab monotherapy in metastatic colorectal cancer. Clin Cancer Res 2010; 16: 2205-2213.

30. Chung KY, Shia J, Kemeny NE et al. Cetuximab shows activity in colorectal cancer patients with tumors that do not express the epidermal growth factor receptor by immunohistochemistry. J Clin Oncol 2005; 23: $1803-1810$

31. Atkins D, Reiffen KA, Tegtmeier CL et al. Immunohistochemical detection of EGFR in parrafin-embedded tumor tissues: variation in staining intensity due to choice of fixative and storage time of tissue sections. $J$ Histochem Cytochem 2004; 52: 893-901.

32. National Comprehensive Cancer Network. NCCN clinical practice guidelines in oncology: colon cancer V2 2015.

33. Dienstmann R, Salazar R, Tabernero J. The evolution of our molecular understanding of colorectal cancer: What we are doing now, what the future holds, and how tumor profiling is just the beginning. Am Soc Clin Oncol Educ Book 2014: 91-99.

34. Domagała P, Kowalik A. Badanie molekularnych markerów wykorzystywanych w leczeniu chorych na raka jelita grubego. Pol J Pathol 2014; 65 (4 Suppl 1): S59-S77.

35. Siena S, Sartore-Bianchi, A Nicolantonio F. Biomarkers predicting clinical outcome of epidermal growth factor receptor-targeted therapy in metastatic colorectal cancer. J Natl Cancer Inst 2009; 101: 1308-1324.

36. Clarke C, Kopetz ES. Braf mutatnt colorectal cancer as a distinct subset of colorectal cancer: clincal characteristics, clinical behaviour and response to targeted therapies. J Gastrointest Oncol 2015; 6: 660-667.

37. Sincirope FA, Shi Q, Smyrk T et al. Molecular markres identify subtypes of stage III colon cancer associated with patient outcomes. Gastroenterology 2015; 148: 88-89.
38. Capalbo C, Marchetti P, Coppa A. Vemurafenib and panitumumab combination tailored therapy in BRAF-mutated metastatic colorectal cancer. Cancer Biol Ther 2014; 15: 826-831.

39. Tie J, Gibbs P, Lipton L et al. Optimizing targeted therapeutic development: analysis of a colorectal cancer patient population with the BRAF(V600E) mutation. Int J Cancer 2011; 128: 2075-2084.

40. Richman SD, Seymour MT, Chambers P et al. KRAS and BRAF mutations in advanced colorectal cancer are associated with poor prognosis but do not preclude benefit from oxaliplatin or irinotecan: resultes from the MRC FOCUS trial. J Clin Oncol 2009; 27: 5931-5937.

41. Mallinger A, Crumpler S, Pichowicz M. Discovery of potent, orally bioavailable, small-molecule inhibitors of WNT signaling from a cell-based pathway screen. J Med Chem 2015; 58: 1717-1735.

42. Siedlecki J, Deptała A, Wojtukiewicz MZ (ed.) Molekularne czynniki prognostyczne i predykcyjne w raku jelita grubego. In: Rak jelita grubego. Poznań: Termedia Wydawnictwa Medyczne, 2012: 34-35.

43. Cunningam Jm, Kim CY, Christensen ER et al. The frequency of hereditary defective mismatch repair in a prospective series of unselected colorectal carcinomas. Am J Hum Genet 2001; 69: 780-790.

44. Vilar E, Scaltriti M, Balmana J et al. Microsatellite instability due to $\mathrm{hMLH} 1$ deficiency is associated with increased cytotoxicity to irinotecan in human colorectal cancer cell lines. Br J Cancer 2008; 99: 1607-1612.

45. Stiegelbauer V, Perakis S, Deutsch A et al. MicroRNAs as novel predic tive biomarkers and therapeutic targets in colorectal cancer. Word J Gastroenterol 2014; 20: 11727-11735.

46. Cantini L, Issela C PC. MicroRNA-mRNA interactions underlying colorectal cancer molecular subtypes. Nat Commun 2015; 6: 8878.

47. Jass JR. Classification of colorectal cancer based on correlation of clinical, morphological and molecular features. Histopathology 2007; 50: 113-130.

48. Sadanandam A, Wang X, de Sousa E et al. Reconciliation of classification systems defining molecular subtypes of colorectal cancer: interrelationships and clinical implications. Cell Cycle 2014; 13: 353-357. 